\title{
“KUĆA ZRINSKIH NIJE NIKAD BILA ISTINSKI DOM OBITELJI ERDŐDY". POGLAVLJA IZ ODNOSA OBITELJI ZRINSKIH I ERDŐDY U RANOM NOVOM VIJEKU*
}

Szabolcs Varga

Pécsi Egyháztörténeti Intézet

Pécsi Püspöki Hittudományi Főiskola

Pečuh, Mađarska

\author{
UDK 929.52Zrinski \\ 929.52Erdődy \\ 94(497.5-3Slavonija)"15/17" \\ Izvorni znanstveni rad \\ Primljeno: 17.6.2015. \\ Prihvaćeno: 18.1.2017. \\ DOI: http://doi.org/10.21857/yl4okf7669
}

U radu se raspravlja o odnosima obitelji Erdődy i Zrinski, dviju velikaških obitelji koje su u razdoblju ranog novog vijeka bile najznačajne obitelji regije i koje su obnašale opetovano dužnost bana Hrvatske i Slavonije. Kako će se vidjeti u samom radu, obitelj Zrinski je držala službu bana punih četrdeset godina, a na njegovoj su se funkciji smjenila čak četiri člana obitelji. S druge pak strane, pet članova obitelji Erdődy je držalo funkciju bana preko sedamdeset godina. Članak stoga, između ostalog, uspoređuje njihov značaj u Slavoniji, ali i na razini Kraljevstva budući da su brojni članovi obitelji imali značajne vojne karijere.

Ključne riječi: obitelj Zrinski, obitelj Erdődy, društvena povijest, politička povijest, rani novi vijek, Slavonija

\section{Uvod}

Hrvatski i mađarski povjesničari, povjesničari umjetnosti i književnosti bavili su se određenim aspektima povijesti obitelji Zrinski u kraćim ili dužim studijama, te bi trebalo uložiti ogroman trud da se sva ta djela skupe u cjelovitoj bibliografiji. ${ }^{1}$

\footnotetext{
* Ovaj je rad financirala Mađarska znanstveno-istraživačka zaklada (OTKA PD-109863). Glavni dio teksta nastao je do jeseni 2014., ali su završni dijelovi nastali do siječnja 2016. godine. Želio bih zahvaliti Terézi Oborni na njezinoj pomoći.

1 Zrínyi i Europa, 2 sv., ur. Jadranka Damjanov, Zagreb 2000.-2003.; Nataša Štefanec, Heretik Njegova Veličanstva. Povijest o Jurju IV. Zrinskom i njegovu rodu, Zagreb 2001.; Povijest obitelji Zrínyi. Zbornik radova sa znanstvenoga skupa što je održan u Palači Matice hrvatske, 8.-9. studenoga 2004., ur. Jelena Hekman, Zagreb 2007., A Zrínyiek a magyar és horvát históriában [Zrinski u mađarskoj i hrvatskoj povijesti], ur. Sán-
} 
Szabolcs Varga: “Kuća Zrinskih nije nikad bila istinski dom obitelji Erdődy”...

Zb. Odsjeka povij. znan. Zavoda povij. druš. znan. Hrvat. akad. znan. umjet., 34 (2016), str. 107-123

Ipak, težak znanstveni rad se isplatio, a kako je mađarska vlada proglasila 2016. godišnjicom Zrinskih, nadamo se da će to omogućiti da spoznaje dopru do šire mađarske javnosti i time postanu dijelom javnog mišljenja.

Nadam se da bi godišnjica, kroz obitelj Zrinski, mogla imati pozitivan utjecaj preko granica Mađarske, poglavito u Hrvatskoj i Austriji, na općenito mišljenje o stotinu godina dugoj zajedničkoj povijesti u Habsburškoj Monarhiji. To bi bilo vrlo važno, budući da se čini da je najveća prepreka tijekom stvaranja odnosa bilo negativno sjećanje na zajedničku prošlost, što se može promijeniti događajima vezanim uz godišnjicu Zrinskih. Povijesti pojedinih pripadnika obitelji koji nose ime Nikola svjedoče da su obojica, i junak Sigeta, i njegov praunuk, pjesnik 17. stoljeća, smatrali multinacionalno kraljevstvo kao njihov prirodan prostor za obitavanje, i ne bi im danas bila jasna pitanja oko njihovog nacionalnog identiteta, budući da su osjećali da su istovremeno dijelom i hrvatskog i mađarskog naroda. ${ }^{2}$

"Godišnjica Nikole Zrinskog - Siget 1566." također daje priliku da Europa obrati pozornost na ugarsko-hrvatsku ulogu, i u širem smislu, povijesnu ulogu središnje Europe, koja je zadržala osmanska osvajanja neizmjernim žrtvovanjima i s pomoći Zapada. Ovo treba naglasiti čak i danas, budući da turske, anglosaksonske i njemačke sinteze nisu priznavale ovo područje ili su potpuno pogrešno shvatile

dor Bene - Gábor Hausner, Budapest 2007.; Militia et Litterae. Die beiden Nikolaus Zrínyi und Europa ur. Wilhelm Kühlmann - Gábor Tüskés - Sándor Bene, Tübingen 2009.; Gene S. Whiting, Zrínyi, Medimurje i reformacija: prilozi poznavanju povezanosti Zrínyih, Međimurja i reformacije u drugoj polovici 16. stoljeća, Zagreb 2009.; Zrínyi Miklós élete és öröksége. A 2008. november 7-8-án Zrínyi Miklós születésének 500. évfordulója alkalmából Szigetváron rendezett konferencia elöadásainak szerkesztett szövege [Život i baština Nikole Zrinskog. Tekstovi sa skupa održanog u Sigetu 7.-8. studenoga 2008. prilikom obilježavanja 500. godišnjice rođenja Nikole Zrinskog), ur. Zoltán Varga, Szigetvár 2010.; Ágnes R. Várkonyi, Európa Zrínyije [Europa Zrinskih], Budapest 2011.; Politička, kulturna i društvena djelatnost Zrínyih $i$ Frankopana u Hrvatskoj. Zbornik radova sa znanstvenog skupa održanog u Čakovcu 6. i 7. listopada 2010., ur. Juraj Kolarić, Čakovec 2011.; Susreti dviju kultura: Obitelj Zrínyi u hrvatskoj i mađarskoj povijesti. Zbornik radova s međunarodnog hrvatsko-mađarskog znanstvenoga skupa održanog u Palači Matice hrvatske 1. listopada 2009., Sándor Bene - Zoran Ladić - Gábor Hausner, Zagreb 2012.; Zrínyi-Újuár emlékezete [Sjećanje na Zrinski - Novigrad], ur. Gábor Hausner - József Padányi, Budapest 2012.; Hír a dicső tettek ragyogása, ur. Szabolcs Varga, Szigetvár 2012.; Gábor Hausner, Márs könyvet olvas. Zrínyi Miklós és a 17. századi hadtudományi irodalom [Mars čita knjigu. Nikola Zrinski i sedamnaestostoljetna vojna literatura], Budapest 2013.; Ivan Kosić, Bibliotheca Zriniana. Katalog izložbe u povodu 350. obljetnice smrti Nikole VII. Zrinskoga, Zagreb 2014.; Költő, hadvezér, államférfi Zrínyi Miklós 1620-1664. [Pjesnik, vojskovođa, državnik. Nikola Zrinski 1620.-1664.], ur. Tibor Rostás, Budapest 2014.; Szabolcs Varga, Studije o povijesti Sigeta i obitelji Zrínyi u 16. stoljeću, Pečuh 2015.

2 Dénes Sokcsevits, Zrinyi Miklós helye a horvát történelmi és nemzeti tudatban [Mjesto Nikole Zrinskog u hrvatskom nacionalnom i povijesnom mijenju], predavanje u Sigetu 8. siječnja 2016.; Géza Pálffy, Egy horvát-magyar főúri család a Habsburg Monarchia nemzetek feletti arisztokráciájában. A Zrínyiek határokon átívelő kapcsolatai [Hrvatsko-ugarska aristokratska obitelj u nadnacionalnoj aristokraciji Habsburške Monarhije. Odnosi obitelji Zrinski preko granica], u A Zrínyiek a magyar és horvát históriában, str. 39-67. Revizija članka: Isti, A szigetvári Zrínyi Miklós a Magyar Királyság és a Habsburg Monarchia arisztokráciájában [Nikola Zrinski Sigetski unutar aristokracije Ugarskog Kraljevstva i Habsburške Monarhije], u: Zrínyi Miklós élete és öröksége, str. 28-48; Isti, Költő és hadvezér? A politikus, katona és költő-író Zrínyi Miklós különféle lojalitásai és identitásai [Pjesnik ili vojskovođa? Političar, vojnik i pisac-pjesnik Nikola Zrinski i njegovi odnosi i identiteti], Hadtörténelmi Közlemények, god. 127, br. 4, Budapest 2014., str. 867-881. 
Szabolcs Varga: “Kuća Zrinskih nije nikad bila istinski dom obitelji Erdődy”...

Zb. Odsjeka povij. znan. Zavoda povij. druš. znan. Hrvat. akad. znan. umjet., 34 (2016), str. 107-123

problematiku oko tursko-ugarskog pograničja. ${ }^{3}$ Zaista, tako smo pripadali periferiji kontinenta u tome razdoblju, i javnost i politika bili su više zainteresirani za događaje u Italiji, Francuskoj i Svetom Rimskom Carstvu, ali pitanja oko vlasti nad ovim područjem nisu bila beznačajna i središnja ratna zona na Dunavu bila je uvijek teritorijem visokog prioriteta za carski sud, koji je bio smješten u Beču od 1556. godine. Svi su ti faktori utjecali na političke strategije drugih europskih sila, na što je utjecao i gorljivi interes kojeg je incirao Zrinski.

\section{Okviri istraživanja hrvatsko-slavonske elite}

Neosporno je da su rezultati istraživanja ranomoderne povijesti obitelji Zrinski važan dio hrvatskog i mađarskog istraživanja društvenih elita. Unatoč mnogobrojnim znanstvenim radovima, svejedno nedostaje evaluacija karijere i značaj obitelji u kontekstu hrvatsko-ugarskih i carskih elita, iako su nam već poznati stadiji uzdizanja nekih drugih baronskih obitelji. ${ }^{4}$ Međutim, ne može se ni danas opisati koliko je bila specifična karijera starog Zrinskog, ili kako karijera njegovog praunuka može biti sagledana u cijelosti, bez da uopće spominjemo druge članove obitelji. Savršenu osnovu za istraživanje ove teme u bližoj budućnosti može pružiti nekoliko studija slučajeva, ${ }^{5}$ uz pomoć metodologije razrađene za procese političkog uspona i karijere, iako je ona razrađena jedino za službe u centralnoj vlasti i carskom dvoru. ${ }^{6}$

Ugarsko Kraljevstvo, koje je regionalno kraljevstvo u srednjem vijeku, u novom je vijeku bilo tako široki teritorij u svojem nepotpunom stanju da su elite određenih njegovih područja mogle biti različite u određenim aspektima. Razlika u slučaju

3 Markus Kohler, Eine Gesellschaft im Wandel - die osmanische Herrschaft in Ungarn im 17. Jahrhundert (1606-1683), Stuttgart 2010.

4 Pálfiovci v novoveku. Vzostup významného uhorského šlachtického rodu. Zborník z vedeckej konferencie Bratislava 20. maja 2003., ur. Anna Fundárková - Géza Pálffy, Bratislava - Budapest 2003.; József Bessenyei, A Nádasdyak [Obitelj Nádasdy], Budapest 2005.; István Fazekas, Szalaházy Tamás, egy Habsburg-hú főpap portréja [Tamás Szalaházy, portret prelata odanog Habsburzima], Történelmi Szemle, god. 49, br. 1, Budapest 2007., str. 19-35; Tibor Neumann, A Korlátköviek. Egy elökelő család története és politikai szereplése a 15-16. században (Obitelj Korlátkövi. Povijest i politička uloga jedne aristokratske obitelji u 15. i 16. stoljeću], Győr 2007.; Géza Pálffy, Különleges úton a Magyar Királyság arisztokráciájába. A Révay család a 16. században [Na posebnom putu do aristokracije Ugarskog Kraljevstva. Obitelj Révay u 16. stoljeću], Történelmi Szemle, god. 51, br. 1, Budapest 2009., str. 1-20; Isti, Pozsony megyéből a Magyar Királyság élére. Karrierlehetóségek a magyar arisztokráciában a 16-17. század fordulóján (Az Esterházy, a Pálffy, és az Illésházy család felemelkedése) [Od Požunske županije do vrha Ugarskog Kraljevstva. Karijerne mogućnosti ugarske aristokracije na prijelazu 16. na 17. stoljeće. Uspon obitelji Esterházy, Pálffy i Illésházy], Századok, god. 135, br. 4, Budapest 2009., str. 862-866; Arisztokrata életpályák és életviszonyok [Aristokratske karijere i životni uvjeti], ur. Klára Papp - Levente Püski, Debrecen 2009., str. 9-24.

5 Müveltség és társadalmi szerepek: arisztokraták Magyarországon és Európában [Kultura i uloge u društvu: aristokrati u Ugarskoj i Europi], ur. Attila Bárány - István Orosz - Klára Papp - Bálint Vinkler, Debrecen 2014.

6 Géza Pálffy, A Magyar Királyság és a Habsburg Monarchia a 16. században [Ugarsko Kraljevstvo i Habsburška Monarhija u 16. stoljeću], Budapest 2010., str. 121-136. Za istraživanje ranomoderne češke aristokracije, vidi: Petr Mat'a, Svět české aristokracije (1500-1700), Edice Česká historie, sv. 12, Praha 2004. 
Szabolcs Varga: “Kuća Zrinskih nije nikad bila istinski dom obitelji Erdődy”...

Zb. Odsjeka povij. znan. Zavoda povij. druš. znan. Hrvat. akad. znan. umjet., 34 (2016), str. 107-123

erdeljske elite bila je očita od početaka, ${ }^{7}$ i aristokratsko društvo Slavonije i Hrvatske - dva područja takozvanih "Južnih ugarskih zemalja", koja su se tijekom vremena smanjivala i postupno ujedinila, također ima slične značajke. ${ }^{8}$ Međutim, da situacija bude još kompliciranija, bilo je i puno razlika između karakteristika elita tih dvaju područja (Hrvatske i Slavonije) - u identitetu, povijesnoj tradiciji, te činjenici da je hrvatska aristokracija bila više zatvorena zajednica, što se djelomično može objasniti geografskim obilježjima. To je bilo točno za najužu elitu hrvatske aristokracije: Blagajske, Frankopane i Krbavske, a također i za obitelj Zrinski, koja se pridružila toj eliti u 16. stoljeću. Približila ih je činjenica da su imali titulu nasljednih grofova, koja se rijetko koristila sjeverno od rijeke Save, pa je vjerojatno označavala veliki prestiž za onoga tko ju je imao u plemićkom društvu. ${ }^{9}$

Slavonska elita bila je više heterogena negoli hrvatska aristokracija. Lokalni veleposjednici nestali su tijekom kasnoga srednjeg vijeka, a pridošlice koji su bili djelomično s južnih, hrvatskih područja, i djelomično ugarskog porijekla preuzeli su njihove posjede. Povrh toga, ugarska je dvorska aristokracija također željela zadobiti zemlju u Slavoniji. ${ }^{10}$ Dakle, baruni s tog područja bili su više povezani s ugarskom središnjom administracijom, i može se pretpostaviti da, do razdoblja Jagelovića, nije postojao regionalni identitet, isto kao što bi bilo povijesno neutemeljeno pričati o "transdunavskoj" ili "gornjeugarskoj" aristokraciji.

Promjene u društvu uzrokovala su osmanska osvajanja, gubitak teritorija, rušenje carskog dvora u Budimu i njegov premještaj u Beč, gradnja, održavanje i upravljanje habsburškom vojnom linijom obrane, te počeci administrativnih reformi. Smatram da je tijekom 16. stoljeća aristokratski krug bio formiran među slavonskim plemstvom, čiji su članovi napredovali zahvaljujući ratnim zaslugama u Ugarskoj,

\footnotetext{
Klára Papp, Az erdélyi Csákyak [Erdeljska obitelj Csáky], Kolozsvár 2011.; Ildikó Horn, A könnyezö krokodil. Jagelló Anna és Báthory István házassága [Krokodilske suze. Brak Ane Jagelović i Stjepana Báthoryja], Budapest 2007.; Teréz Oborni, Udvar, állam és kormányzat a kora újkori Erdélyben. Tanulmányok [Dvor, država i vlada u ranomodernom Erdelju. Studije], Budapest 2011.

8 Géza Pálffy, Horvátország és Szlavónia a XVI-XVII. századi magyar királyságban [Hrvatska i Slavonija u Ugarskom Kraljevstvu u 16. i 17. stoljeću], u: Tanulmányok a 60 éves Gecsényi Lajos tiszteletére [Studije u čast Lajosa Gecsényija povodom njegovog šezdesetog rođendana], Fons (Forráskutatás és Történeti Segédtudományok), god. 9, sv. 1-3, Szeged 2002., str. 107-121. Više o tome: Dénes Sokcsevits, Horvátország a 7. századtól napjainkig [Hrvatska od 7. stoljeća do današnjih dana], Budapest 2011., str. 160-224. Još jedan kratki prikaz: Szabolcs Varga, Horvátország és Szlavónia a kora újkorban [Hrvatska i Slavonija u ranom novom vijeku], u: Mozaikok a Magyar Királyság 16-17. századi történelméból [Mozaici povijesti Ugarskog Kraljevstva u 16. i 17. stoljeću], ur. Zoltán Péter Bagi - Adrienn Horváth, Budapest 2012., str. 35-57.

9 Géza Pálffy, A grófi cím a 16-17. századi Magyarországon és Erdélyben [Titula grofa u Ugarskoj i Erdelju u 16. i 17. stoljeću], u: “... éltünk mi sokáig 'két hazában..." Tanulmányok a 90 éves Kiss András tiszteletére [“... mi smo dugo živjeli u dvije domovine..." Studije u čast Andrása Kissa povodom njegovog devedesetog rođendana], ur. Veronika Dáné - Teréz Oborni - Gábor Sipos, Debrecen 2012., str. 177-193, ovdje posebice str. 181-182.

10 Usp. Szabolcs Varga, Obitelj Bátori u Slavoniji, Zbornik Odsjeka za povijesne znanosti Zavoda za povijesne i društvene znanosti Hrvatske akademije znanosti i umjetnosti, sv. 31, Zagreb 2013., str. 161-180.
} 
posebice u Sigetu. ${ }^{11}$ Bilo koja vrsta slavonskog identiteta - koja nije isključivalo ikoju drugu samoidentifikaciju - bila je formirana tijekom čestih provincijskih skupština i trajnih vojnih kampanja, dokazi čega su bili simboli njihove posebnosti: pečat, zastava i grb, koji su bili potpuno formirani šezdesetih godina 16. stoljeća. ${ }^{12}$

Iz redova slavonskog plemstva, tijekom sredine 16. stoljeća, sljedeći su se pojedinci ili cijele obitelji uzdigle na rang baruna: obitelj Ráttkay, Grgur Farkašić, koji je bio kapetan Sigeta, Marko Horvat, obitelj Kaštelanović, obitelj Alapić, obitelj Gregorijanac, Benedikt Túróci, koji je bio ban Slavonije, i Mihovil Konjski. To znači da je od 85 novih baruna toga razdoblja 11 ljudi, odnosno 13\%, poteklo iz Slavonije, prostora veličine samo $20,000 \mathrm{~km}^{2} .{ }^{13}$ Povrh toga, ako uzmemo u obzir i dalmatinsko-hrvatske nove barune: obitelji Keglević (1646.), Drašković (1567.), Malakóczy (1614.), Mikulić (1635.-1637.), ${ }^{14}$ Oršić, Delišimunović, Vojnović, Jelačić (obje 1675.), Makár (1687.), i Čikulin, koji su bili talijanskog porijekla (1626.) ${ }^{15}$ možemo govoriti o južnoslavenskoj aristokracijom. ${ }^{16}$ Iako je ta skupina bila povezna s elitom Ugarskog Kraljevstva i Habsburške Monarhije na puno razina, $\mathrm{u}$ isto je vrijeme postojalo nekoliko razlika između njih. Istraživanje ove teme još uvijek nije dovršeno, i ovaj podugačak uvod predstavlja kompleksnost i nerješivost ovog problema. Zaista je nemoguće pisati o odnosu aristokratskih obitelji Zrinski i Erdődy bez uzimanja u obzir te faktore. Jasno je da je kraljevstvo u kojem su aristokratske obitelji bile značajnije odgovaralo plemstvu, pa je podrijetlo obitelji i njihova tradicija bilo neizbježno pitanje za obitelji poput Zrinskih, Frankopana, Túróci i ostalih. Naime, početak odcjepljivanja ovog područja od Ugarskog Kraljevstva može biti povezan s otuđenjem lokalnog plemstva od Svete Ugarske Krune i pojavom nove ideje o Ilirskom Kraljevstvu. ${ }^{17}$

\section{Zrinski i Erdődy na položaju bana}

Među hrvatsko-slavonskom aristokracijom tijekom ranomodernog razdoblja dvije obitelji bile su izrazito ugledne: dovoljno je samo pogledati popis imena

11 Za kasnosrednjovjekovno slavonsko plemstvo, vidi: Tamás Pálosfalvi, The Noble Elite in the County of Körös (Križevci), 1400-1526, Budapest 2014.

12 Szabolcs Varga, Erdődyek, Kerecsényiek, Ráttkayak. A szlavóniai arisztokrácia felemelkedése és bukása a 16. században [Obitelji Erdődy, Kerecsényi i Ráttkay. Uspon i pad slavonske aristokracije u 16. stoljeću], u: Müveltség és társadalmi szerepek, str. 244-245.

13 Za popis imenovanja baruna, vidi: Pálffy, Magyar Királyság, str. 169-172. Za zaključke: Varga, Erdődyek, str. 241-242.

14 Vrijeme imenovanja Tome Mikulića, glavnog suca Ugarske, je nesigurno. Cf. István Csízi, Észrevételek a magyar főnemesi címek XVI-XVII. századi használatához [Observacije korištenju ugarskih aristokratskih titula u 16. i 17. stoljeću], Fons, god. 21, br. 1, Budapest 2011., str. 19.

15 Nikolaus von Preradovich, Das kroatische Element in der ungarischen Adelsnation, Ungarn Jahrbuch, sv. 9, 1978, str. 43-95. Vidi za sve: Ivan Bojničić, Der Adel von Kroatien und Slavonien. Nürnberg 1899. passim.

16 MNL OL A 57. Libri Regii. Vidi: András Koltai, A magyar arisztokrácia családi kapcsolatrendszere a 16-17. században. Magyar bárói rangemelések [Obiteljske mreže ugarske aristokracije u 16. i 17. stoljeću. Uspon ugarskih baruna], dostupno na: http://archivum.piar.hu/arisztokrata/.

17 Sándor Bene, Egy kanonok három királysága. Ráttkay György horvát históriája [Tri kraljevstva jednog kanonika. Hrvatska povijest Jurja Ráttkaya], Budapest 2000. 
Szabolcs Varga: “Kuća Zrinskih nije nikad bila istinski dom obitelji Erdődy”...

Zb. Odsjeka povij. znan. Zavoda povij. druš. znan. Hrvat. akad. znan. umjet., 34 (2016), str. 107-123

hrvatsko-slavonskih banova. ${ }^{18}$ Pozorno promatrajući popis pojedinaca na banskoj časti, mogu se usporediti Zrinski, i dosad nespomenuti Erdődy od Monyorókeréka. Dok uloga prvog nije iznenađujuća, jer se to ime gotovo sjedinilo s pojmom banske službe, ulogu drugog potrebno je detaljnije objasniti.

Među Zrinskima su četiri člana obitelji bili nosioci ove titule u kraćim ili dužim razdobljima. Prvo ime na popisu je Nikola Zrinski, junak Sigeta (1542.-1556.), a nakon njega slijedi njegov unuk Juraj II. (1622.-1627.), potom pjesnik Nikola (1648.1664.), i popis završava s tragičnim Petrom (1665.-1670.). Ta četvorica Zrinskih bili su na čelu Hrvatske i Slavonije sveukupno 40 godina tijekom 16. i 17. stoljeća, što je 20\% vremena tijekom 200 godina. Proučavajući vremenske karakteristike njihove službe, određena nejednakost je očita od samog početka, budući da su trojica obavljali službu tijekom 17. stoljeća, i štoviše, Nikola i Petar su bili banovi više od 20 godine slijedeći jedan drugoga na tom položaju. Tih 20 godina donijelo je značajne promjene u životu lokalnog plemstva, a i također kraljevske politike općenito. $\mathrm{Hr}$ vatsko-slavonsko plemstvo, sukladno onome ugarskom, istovremeno ujedno služeći kao protuteža i dijeleći ipak nezadovoljstvo carskim dvorom u Beču - izgradilo je novu povijesnu tradiciju za sebe, što danas možemo smatrati ranoilirskim pokretom. ${ }^{19}$ Možda je začuđujuće, ali razdoblje između 1650. i 1670. bilo je potpuni neuspjeh: nije uspješno zaustavljeno osmansko osvajanje i izgubljeno je povjerenja Habsburškog dvora kao rezultat Zrinsko-Frankopanske urote (urote Wesselényija u mađarskoj historiografiji). ${ }^{20}$ Smaknuća u Bečkom Novom Mjestu jasno su pokazala da osim dvorskog i katoličkog krila ne postoji alternativa unutar carske politike, pa su Nikolini i Petrovi planovi o nezavisnosti propali. Nije slučajnost da su, nakon neuspjeha urote, Zrinski bili istisnuti iz svoje uske provincije iz koje potječu, i do izumiranja obitelji 1703. nisu mogli vratiti svoje položaje. Unatoč tome, nastao je važan kult obitelji u ranomodernom razdoblju, koji je i dan danas prisutan, a ojačan je do ere baroka, romantizma i nacionalizma, ali njegova osnova, potrebno je naglasiti, nije bila rezultatom njihovog političkog uspjeha. ${ }^{21}$

18 To je napravio Géza Pálffy, kojem bih želio zahvaliti jer mi je dozvolio da konzultiram rukopis.

19 Zrinka Blažević, Ilirizam prije ilirizma, Zagreb 2008., Bene, Egy kanonok, passim.

20 Géza Pálffy, A szakítások és kiegyezések évszázada: a Magyar Királyság 17. századi története új megvilágításban [Stoljeće prekida i dogovora: povijest Ugarskog Kraljevstva u 17. stoljeću u novom svijetlu], Történelmi Szemle, god. 57, br. 1, Budapest 2015., str. 59; Bene, Egy kanonok, str. 45.

21 Géza Galavics, Kössünk kardot az pogány ellen. Török háborúkés képzömüvészet [Podignimo mačeve protiv pogana. Osmanski ratovi i umjetnost], Budapest 1986.; Gizella Cennerné Wilhelmb, A Zrínyi család ikonográfiája [Ikonografija obitelji Zrinski], Budapest 1997.; Történelem - kép. Szemelvények múlt és müvészet kapcsolatából Magyarországon [Povijest - slika. Izvodi iz odnosa prošlosti i umjetnosti], ur. Árpád Mikó - Katalin Sinkó, Budapest 2003., passim; Sándor Iván Kovács, Szigetvár "veszedelmei" a magyar irodalomban [Prijetnje Sigetom u mađarskoj književnosti], u: Szigetvár története. Tanulmányok a város múltjából [Povijest Sigeta. Studije o prošlosti grada], ur. Sándor Bősze - László Ravazdi, Szigetvár 2006., str. 368-373. 
Szabolcs Varga: “Kuća Zrinskih nije nikad bila istinski dom obitelji Erdődy”...

Zb. Odsjeka povij. znan. Zavoda povij. druš. znan. Hrvat. akad. znan. umjet., 34 (2016), str. 107-123

Imamo puno manje podataka o obitelji Erdődy, no ipak mogu se rekonstruirati osnovne faze karijera pojedinih članova obitelji koji su bili na položaju bana. ${ }^{22}$ Pet članova obitelji, koja potječe od ostrogonskog nadbiskupa Tome Bakača, bili su banovi tijekom 16. i 17. stoljeća. Zagrebački biskup Šimun (1529.-1534.) bio je ban zbog naklonosti Ivanu Zapolji, tijekom zaista turbolentnog razdoblja. Sljedeći ban iz obitelji bio je Petar (II.) (1556.-1567.), a njega slijedi Toma, koji je obnašao tu službu u dva navrata (1583.-1595. i 1608.-1615.). Iz ove obitelji, u 17. stoljeću su bila dva bana, prvo Žigmund Erdődy (1627.-1639.), te potom Nikola (1670.-1693.), koji je bio vrlo ugledan član obitelji, i obnašao je ovu službu najduže u razdoblju ranomoderne ere. Potonje je točno samo ako se računa da su nakon uhićenja Petra Zrinskog, Nikola i zagrebački biskup Nikola Borković bili banski namjesnici, a od 1673. Erdődy je sam obnašao tu službu do 1678., kada ga je Leopold I. postavio za bana. De iure, bio je ban 15 godina, ali u stvarnosti njegov utjecaj i moć bili su neosporivi tijekom sedamdesetih godina 17. stoljeća. Tako je obitelj Erdődy obnašala bansku službu u Slavoniji i Hrvatskoj 30 godina više negoli obitelj Zrinski, točnije ukupno 70 godina, odnosno $35 \%$ proučavanog perioda. Što se banske službe tiče, razlika između dvije obitelji je očita, i možemo dodati da su Erdődyjevi isto obnašali ovu službu i u 18. stoljeću; dovoljno je spomenuti službu Ivana Erdődyja (1790.-1806.).

Može se bez oklijevanja reći da su Erdődyjevi dobro upravljali svojom provincijom, čak uspješnije od Zrinskih. Bez detaljnog nabrajanja, prvo je Petar (II.) Erdődy (1504.-1567.) primio 1565. titulu grofa, koju je zaslužio zbog svoje vojne službe. ${ }^{23}$ Stečena titula comes perpetuus Montis Claudii očito je bila fiktivna časna titula, koja možda ima porijeklo u lažnoj humanističkoj identifikaciji zemlje Moslavine, koja je bila dio obiteljskih posjeda, ali to nije smetalo nasljednicima, koji su nastavljali koristiti tu titulu prilikom izdavanja svojih dokumenata. ${ }^{24}$

Toma (II.) Erdődy (1558.-1624.) imao je najuspješniju karijeru. Iako još nije napisana njegova moderna biografija, njegova važnost ipak je dobro poznata. ${ }^{25}$ Započeo je svoju vojnu karijeru 1578. i radio je sistematski kako bi dosegnuo sam vrh aristokracije; bio je kraljevski savjetnik 1583., obnašao je bansku službu u dva navrata

22 Orsolya Bubryák, Családtörténet és reprezentáció. A galgóci Erdődy-várkastély gyüjteményei. [Obiteljska povijest i reprezentacija. Zbirka Erdődyjeve utvrde Galgóc], Budapest 2013.; Marko Bedić, Velikaška obitelj Erdödy, uspon i pad, Kaj. časopis za knjižernost, umjetnost i kulturu, god. 29, br. 3, 1996., str. 31-52; Isti, Hrvatska velikaška obitelj Erdödy, Zbornik Moslavine, sv. 5-6, 2002.-2003., str. 47-64; Lovro Manenica, Grofovi Erdody u ozračju hrvatske povijesti, Novi Marof 1993.; Borbála Benda - András Koltai, Kutatások az Erdődy család bécsi levéltárában [Istraživanja u arhivu obitelii Erdődy u Beču], Lymbus, 2008., str. 429-461; Borbála Benda, Az Erdődy család 17. századi genealógiája [Sedamnaestostoljetna genealogija obitelji Erdődy], Turul, god. 80, br. 4, Budapest 2007., str. 109-125; Géza Pálffy, A Pálffy család felemelkedése a 16. században [Uspon obitelji Pálffy u 16. stoljeću], u: Pálfiovci v novoveku, str. 17-37.

23 Pálffy, A grófi cím, str. 181-182.

24 Endre Tóth, Továbbélő ókor, u: Történelem - kép, str. 266. Petar II. Erdődy početo je koristiti tu titulu od 1562. godine. Emilij Laszowski, Kako su Ivančići u Dvorjanima postali “plemići” bana Petra Erdőda, Vjesnik Kraljevskog državnog arkiva u Zagrebu, sv. 7, Zagreb 1937., str. 157-161. Ta se titula prvi put spomenula u kraljevskim privilegijima šezdesetih godina 16. stoljeća. MNL OL A 57. Libri regii III. vol. 657-659.

25 Karlo Horvat, Toma Erdedi-Bakač, ban hrvatski, Zagreb 1900. 
Szabolcs Varga: “Kuća Zrinskih nije nikad bila istinski dom obitelji Erdődy”...

(1603.-1608. i 1615.-1624.) i povrh toga, bio je kandidat za palatina Ugarske četiri puta (1608., 1609., 1618., i 1622.), ali su protestantski staleži spriječili njegov izbor. Također je imao uspješnu vojnu karijeru, a njegov najveći uspjeh može se povezati s bitkom kod Siska 1593. godine, zbog čega je bio izabran 20. siječnja 1619., kao jedini među ugarskom aristokracijom, za člana vojnog reda Krv Isusa Krista u Mantui. ${ }^{26} \mathrm{Ru}-$ dolf II. Habsburški potvrdio je obiteljsku titulu grofa kao priznanje za njegove zasluge i 1580. dao im je novu verziju grba. Također je 24. ožujka 1607. dobio titule capitaneus perpetuus utvrde $\mathrm{u}$ Varaždinu i comes perpetuus čitave županije. ${ }^{27}$ Osim toga, Toma je poznat po tome što je bio veliki patron umjetnosti, a način na koji je predstavljao obitelj, učinio ga je istaknutim i uglednim aristokratom svog doba. ${ }^{28}$

Žigmund, sin Tome Erdődyja (1593.-1639.), manje je poznata povijesna ličnost: obnašao je bansku službu 12 godina, oženio je Anu Keglević, a manjak imenovanja na dvorske službe pokazuje da, iako je bio upoznat s dvorskim krugovima u Monarhiji, nije mogao postati dio njih. ${ }^{29}$

Nikola (II.) Erdődy (1631.-1693.) bio je istaknuti član hrvatske grane obitelji, koja potječe od Petra (III.). Kao rezultat njegovih vojničkih sposobnosti i odanosti dvoru, upravljao je provincijama dva desetljeća. Osmanlije su bili istisnuti iz Slavonije tijekom njegove službe, a na njegovom grobu u zagrebačkoj katedrali je zastava provincije i žezlo, za koje se smatralo da su znakovi službe tijekom njegovog banskog imenovanja. Nikola Erdődy, kao jedan od najuspješnijih aristokrata svojeg vremena, balansirajući između nezadovoljnih redova i nepovjerljivog kraljevskog dvora kao uspješan vojskovođa, imao je neospornu ulogu u oslobađanju Slavonije, kojom je upravljao.

Ovaj kratak pregled dovoljan je da se dokaže kako sljedeće mišljenje podcjenjuje ulogu Erdődyja: "Erdődyji nisu među najistraživanijim ranomodernim aristokratskim obiteljima, a razlog tome je vjerojatno činjenica da ne postoje istaknute ličnosti među njima, za razliku od obih obitelji Esterházy, Zrinski, Nádasdi ili Pálffy, koje obiluju takvim figurama. Nijedan od njih nije dostigao najvišu službu u zemlji, onu palatina, i prvi kraljevski sudac (iudex curiae regis) među njima bio je izabran tek $\mathrm{u}$ 18. stoljeću" ${ }^{30}$ Imali su sve elemente za formiranje kulta obitelji - vojni uspjeh, obiteljske veze, dvorske službe - a primjerice čak ni Zrinski nisu obnašali funkciju palatina, ali ta činjenica nije utjecala na njihov doživljaj. Unatoč svemu ovome, Erdődy nisu ušli u nacionalno sjećanje, nikakav kult se nije razvio oko njih, iako su imali mogućnost za to ne samo u mađarskoj, nego i u hrvatskoj, austrijskoj i slovačkoj kulturi, gdje su bili poznati po svojim posjedima i obiteljskim vezama. Razlozi se ne mogu naći u njihovim stvarnim političkim dostignućima.

\footnotetext{
${ }_{26}$ Österreichisches Staatsarchiv (dalje: ÖStA), Haus- Hof- und Staatsarchiv (dalje: HHStA), Familienarchiv Erdődy (dalje: FAE), Depot (dalje: D) 11338. Vidi: Bubryák, Családtörténet, str. 88.

27 ÖstA, HHStA, FAE, D 11321.

28 Bubryák, Családtörténet, str. 92-112.

29 Géza Pálffy, Magyar arisztokraták - horvát nemesek [Ugarski aristokrati - Hrvatski plemići], História, god. 32, br. 5-6, 2011., str. 26.

30 Benda - Koltai, Kutatások, 419.
} 
Szabolcs Varga: "Kuća Zrinskih nije nikad bila istinski dom obitelji Erdődy"...

Zb. Odsjeka povij. znan. Zavoda povij. druš. znan. Hrvat. akad. znan. umjet., 34 (2016), str. 107-123

\section{Počeci odnosa obitelji Zrinski i Erdődy}

Rijedak je slučaj da se treba dokazivati antipatija i nepovjerenje između dviju obitelji, ali u slučaju obitelji Erdődy i Zrinski je upravo takva situacija. Citat izabran za naslov rada nije bio slučajan, već je preuzet iz napisa supruge Emerika Erdődyja, Eve Forgač iz drugoj polovici 17. stoljeća. ${ }^{31}$ Dobro poznate priče o smrti Ivana Zrinskog nakon tučnjave sa Šimunom Erdődyjem 1541., ili o svađi pjesnika Nikole Zrinskog s Emerikom Erdődyjem pedesetih godina 17. stoljeća, ${ }^{32}$ ili o vodećoj ulozi Nikole Erdődyja u zaplijeni imovine sve potvrđuju tu ideju. ${ }^{33} \mathrm{U}$ isto vrijeme, potrebno je napomenuti da su poznati određeni slučajevi kada su određeni članovi obitelji lijepo surađivali. Na primjer, Toma Erdődy i Juraj Zrinski surađivali su tijekom petnaestogodišnjeg rata, pa ne bi trebali promatrati njihov odnos kao drevnu mržnju Capuletija i Montecchija, nego kao neku vrstu udaljavanja, a iza toga je moglo stajati nekoliko stvari; od različitih političkih mišljenja do sukoba interesa. Međutim, može se vjerovati da, osim u nekim slučajevima, dvije obitelji nisu pomagale jedna drugoj prilikom izgradnje političkih karijera.

Te dvije dinastije nisu se međusobno ženile tijekom tih dvaju stoljeća, što dodatno podržava ideju o trajnoj nenaklonosti. ${ }^{34}$ Obje obitelji su preferirale iste aristokratske krugove u slučaju ženidba: Erdődyji su se većinom ženili za obitelji Tahy, Ungnád, Stubenberg, Thurzó, Ráttkay, Drašković, Túróci i Keglević, isto kao i Zrinski. Najveća razlika između dviju obitelji je ta što su Zrinski, tijekom nekoliko generacija, birali svoje parove iz carske aristokracije, dok su to Erdődyji mogli u manje slučajeva: Toma (II.) Erdődy oženio je Anu Mariju Ungnád (iz obitelji ugarskog porijekla), a njegov brat Petar (III.) (1560.-1613.) oženio je Suzanu Stubenberg, dok je ban Nikola (II.) oženio Izabelu Gallenbert. Iako ove brakove ne treba podcijeniti, ipak je razdoblje najvećeg procvata obitelji bilo 18. stoljeće, kada su se ženili s obiteljima Csáky, Esterházy, Trautmannsdorf, Herberstein i Kinsky.

S obzirom na nekoliko mogućih veza između obitelji, čini se da je udaljavanje među njima bila namjerna odluka. Glavni razlog ovog udaljavanja vjerojatno su bila tri neuspješna pokušaja sklapanja braka, i slijedom toga, nekoliko sporova oko posjeda. Vilmos Fraknói je već spomenuo da je Toma Bakač, tijekom stjecanja zemlja u Slavoniji i Hrvatskoj, pokušao izgraditi povoljne obiteljske odnose s nekoliko lokalnih

31 “Tudgya az Ur hogy az Zrinyi Ház, soha az Erdeödy házhoz ighaz nem volt, csak az Urnak küssebsgére s gyalázattyára" (ÖstA, HHStA, FAE, Lad. 101. Fasc. 19.). Citat preveden iz: Bubryák, Családtörténet, fusnota 370.

32 Éva Somogyi, Adalék Zrínyi és az 1653-59. évi horvátországi parasztfelkelés történetéhez [Prilozi povijesti Zrinskih i hrvatski seljački ustanak između 1653. i 1659.], Irodalomtörténeti Közlemények, god. 67, br. 2, Budapest 1963., str. 232-236.

33 Anđelko Mijatović, Zrinsko-frankopanska urota, Zagreb 1992. Vidi i: Levente Nagy, Pethő Gergely rövid magyar krónikája és a Zrínyiek [Kratka hrvatska kronika Grgura Pethőa i Zrinski], Irodalomtörténeti Közlemények, god. 102, br. 3-4, Budapest 1998., str. 288.

34 O obitelji Erdődy, vidi: Bubryák, Családtörténet, a za Zrinske, Pálffy, Egy horvát-magyar fő́ri család, str. 50. 
Szabolcs Varga: “Kuća Zrinskih nije nikad bila istinski dom obitelji Erdődy”...

Zb. Odsjeka povij. znan. Zavoda povij. druš. znan. Hrvat. akad. znan. umjet., 34 (2016), str. 107-123

zemljoposjednika. ${ }^{35}$ Za vrijeme ovoga dirigirao je zaruke svoje nećakinje Margarete, kćeri brata Nikole, i Nikole Zrinskog, koji je tada živio na dvoru. Međutim, Nikola je radije izabrao Jelenu Krbavsku, i odustao o zaruka s Margaretom Bakač. Kasniji junak Sigeta, Nikola Zrinski, rođen je iz ovog braka 1508. godine. Nadbiskup je šurovao na dvoru, pa je kralj Ladislav II. osudio Zrinskog na zapljenu svih posjeda, no presuda nikada nije izvršena, pa su Zrinski preživjeli Bakačevu osvetu. ${ }^{36}$

Ostrogonski nadbiskup nije odustao i nekoliko godina kasnije pokušao je zaručiti jednu od sestara već rečene Margarete sa šogorom Nikole Zrinskog, Ivanom Karlovićem Krbavskim, najkasnije 1517. godine. Prema bračnom ugovoru, on bi primio utvrde Krupu i Otok. ${ }^{37}$ Inače bi, u slučaju preuranjene smrti mladoženje, posjedi obitelji Krbavski u Lici i Bosni postali posjedi Bakača. ${ }^{38}$ Ova točka ugovora bila je u kontradikciji s nasljednim ugovorom što ga je Ivan Krbavski imao s obitelji Zrinski od 1509., koji bi im dao ranije spomenute posjede. ${ }^{39}$ Međutim, čini se da ovaj brak nije zaživio, ${ }^{40}$ no mogao je zaintrigirati Zrinske da izbjegnu manevre Bakača.

\section{Bračni ugovor Erdődyja i Zrinskih}

Godinama nakon bitke kod Mohača obitelj Zrinski bila je na strani Ferdinanda, dok su Erdődyji podupirali Ivana Zapolju, da bi tridesetih godina 16. stoljeća prešli na stranu Habsburgovaca. Nakon 1535. obje su obitelji pripadale istoj političkoj strani, međutim, sukobi između Zrinskih i zagrebačkog biskupa Šimuna Erdődyja bili su svakodnevna pojava. Tijekom jednog od tih sukoba, 1541., umro je Ivan Zrinski. ${ }^{41}$ Vjekoslav Klaić naglasio je da se nakon ovog formirao ne samo bliski odnos, nego i prijateljstvo između Nikole Zrinskog i Petra (II.) Erdődyja. ${ }^{42}$ Navod se ne može potpuno provjeriti, ali činjenica je da su obitelji postale povezane preko brakova s obitelji Tahy: Ivan Zrinski, Nikolin brat, oženio je Anu Tahy prije 1541., a Petar Erdődy Margaretu Tahy vjerojatno nakon 1546. godine. ${ }^{43} \mathrm{Ne}$ znam koliko su bile bliske dvi-

35 Vilmos Fraknói, Bakócz Tamás prímás birtokszerzeményei [Zemljišne akvizicije primasa Tome Bakača], Századok, god. 20, br. 1-2, Budapest 1888., str. 97-128; Pálosfalvi, The Noble Elite, str. 391.

36 Vilmos Fraknói, Erdődy Bakócz Tamás élete [Život Tome Bakača], Budapest 1889., str. 172-174; Bubryák, Családtörténet, str. 42

37 Fraknói je vjerovao da se vjenčanje dogodilo 1517., ali to nije vjerojatno, cf.: Fraknói, Bakócz Tamás prímás birtokszerzeményei, str. 114 .

38 Ivan Filipović, Ispisi iz Središnjeg arhiva obitelj Erdödy u Središnjem arhivu u Bratislavi, Arhivski vjesnik, sv. 21-22, Zagreb 1978.-1979., str. 190.

39 Szabolcs Varga, Adalékok a Zrínyi család felemelkedéséhez. A Karlovics-örökség [Prilozi usponu obitelji Zrinski. Ostavština Karlovića], u: Zrínyi Miklós élete és öröksége, str. 4-28.

40 "videtur perseverare circa matrimonium in proposito, sed certe non habet quo illa $(m)$ sponsam ducat..." (MNL OL, DF 261 759). Želio bih zahvaliti Tamásu Pálosfalviju što mi je ukazao na ovaj dokument.

${ }^{41}$ Zrínyi Miklós a szigetvári hös életére vonatkozó levelek és okiratok [Pisma i dokumenti za život sigetskog heroja Nikole Zrinskog], sv. 1, ur. Samu Barabás, Budapest 1898., dok. 13, str. 25-26.

42 Vjekoslav Klaić, Povijest Hrvata, sv. 5, Zagreb 1982., str. 270-271. Citat prema: Štefanec, Heretik Njegova Veličanstva, str. 31-32.

43 Ana Tahi potpuno je nepoznata u znanstvenoj literaturi, čak ni Samu Barabás nije mogao naći podatke o njoj, kao što je niti ne spominje monumentalno djelo Ivána Nagya, iako je spomenuo Evu kao Petrovu ženu: Iván Nagy, Magyarország családai czímerekkel és nemzedékrendi táblákkal. XI. vol. [Obitelji Ugarske 
Szabolcs Varga: “Kuća Zrinskih nije nikad bila istinski dom obitelji Erdődy”...

Zb. Odsjeka povij. znan. Zavoda povij. druš. znan. Hrvat. akad. znan. umjet., 34 (2016), str. 107-123

je ženske članice obitelji Tahy i nema izvora koji govore da su Ivan i Petar bili šogori, ali je sigurno da su Erdődyji ostali u kontaktu s Anom Tahy nakon što je postala udovica, i to je vjerojatno bio razlog zašto je mladi Petar založio Ani utvrdu Somlyó i njezine pripadnosti oko 1545 . godine. ${ }^{44}$ Ova obiteljska veza mogla bi biti razlog zbog čega je 1556. Petar Erdődy ponudio Nikoli Zrinskom da uda svoju kćer Anu Erdődy za Nikolinog sina Jurja Zrinskog. ${ }^{45}$ Možemo samo pogađati Petrove razloge za ponudu, ali možda se može objasniti smrću njegove žene i njegovom dugotrajnom bolesti. ${ }^{46}$ Sin udovca Petra već je ranije preminuo, pa je jedini nasljednik oko 1551. bila Ana, ${ }^{47}$ a i Petrova je kćer prefektirana kraljevskom ispravom (praefectio in filium). ${ }^{48}$ Također je 1554. godine donirao nekoliko posjeda Ani: Monyorókerék i Vörösvár, potom posjede u županiji Vas, koji sada pripadaju Austriji, Körmend, koji je bio jedna od glavnih rezidencija obitelji, Somlyó u županiji Veszprém, ${ }^{49}$ iako je potonji u to doba godinama bio u zalogu kod obitelji Chorons od Devecsera. ${ }^{50}$

Među ovima najvrjedniji su bili posjedi Monyorókerék-Vörösvár, s fortifikacijom, utvrdom, dva trgovišta (oppidium), od kojih je jedan bio bogati Vép, s 21 selom, tri manja udjela u posjedima, odakle su značajne prihode donosile obrade vinograda. ${ }^{51}$ Petar (I.) Erdődy se naselio na ovaj posjed koji je 1496. stekao od obitelji Ellenbach. Nakon 1517. ondje je preselio sjedište obitelji, uz pomoć Tome Bakača, koji se najvjerojatnije samoodređivao prema imenu posjeda..$^{52} \mathrm{U}$ oporuci iz 1544 . godine

S grbovima i genealoškim tablama], Pest 1865., str. 7-8. Spomen Ane Tahi, 25. rujna 1546.: MNL OL MKA E 185

44 Tibor Koppány, A Veszprém megyei Somlyó vára története [Povijest utvrde Somlyó u županiji Veszprém], Magyar Müemlékvédelem, sv. 14, 2007., str. 20-21.

45 Bubryák, Családtörténet, str. 90-91. Iako je ugovor nastao 1557., pregovori su počeli godinu dana ranije. ÖstA, HHStA, FAE, Lad. 52. fasc. 4. no. 7 (s.d.).

46 Margareta se još uvijek pripremala za hodočašće u Loretto 1554., ali se ne spominje više u bračnom ugovoru dvije godine kasnije "Szerelmes Orsikám..." A Nádasdyakés Szegedi Kôrös Gáspár levelezése [“Moja voljena Uršika”. Korespondencija između obitelji Nádasdy i Gašpara Szegedi Kőrös], prir. Tivadar Vida, Budapest 1988., str. 83-84. O trbušnoj bolesti Petra Erdődyja: Sándor Payr, A dunántúli evangélikus egyházkerület története [Povijest luteranske dijaceze Transdanubije], sv. 1, Sopron 1924., str. 274. O njegovoj oporuci, vidi: Bubryák, Családtörténet, str. 91.

47 O Ani Erdődy, cf.: Árpád Mikó - Géza Pálffy, A pozsonyi Szent Márton templom késő reneszánsz és kora barokk síremlékei (16-17. század) [Renesansni i ranobarokni grobovi u crkvi sv. Martina u Bratislavi tijekom 16. i 17. stoljeća], Müvészettörténeti Értesítő, sv. 51, 2002., str. 131-132.

48 ÖStA, HHStA, FAE, Lad. 52. fasc. 4. No. 12; MOL E 200 Acta diversa Fam. Erdődy család 7. cs. Irrgestreata fol. 40

49 MNL OL P 1341. Lad. 18. fasc. 1. no. 3.

50 ÖStA, HHStA, FAE, Lad. 54. fasc. 1. No. 19. Szabolcs Varga, A devecseri Choronok, Fons, god. 8, br. 1, Budapest 2001., str. 259-311, posebice str. 266-267.

51 MNL OL E 185 b. III. 13. it. Monyorókerék-Vörösvár. No. 28. O Vörösváru, vidi: Josef Loibersbeck, Eberau und Rotenturm, Volk und Heimat, sv. 14, 1961., str. 17-24, sv. 15, 1962., str. 1-7. O Vépu, vidi: Sisa József, A vépi volt Erdődy-kastély Vas megyében [Nekadašnja utvrda Erdődy u Vépu], Müemlékvédelem, sv. 21, 1977., str. 170-172.

52 26. rujna 1518. (MNL OL DL 89127); 20. prosinca 1522. (MNL OL DL 101560). Petar Erdődy pisao je pismo Gabrielu Salamanci, koji je bio rizničar nadvojvode Ferdinanda I. Habsburškog u korist zagrebačkog biskupa Šimuna Erdődyja 6. travnja 1524. (ÖStA, HHStA Ungarische Akten Allgemeine Akten Fasc. 1. Konv. D. 86). 
Szabolcs Varga: “Kuća Zrinskih nije nikad bila istinski dom obitelji Erdődy”...

Zb. Odsjeka povij. znan. Zavoda povij. druš. znan. Hrvat. akad. znan. umjet., 34 (2016), str. 107-123

ostavio je ovaj posjed svojoj ženi, Doroteji Puchaim, uz uvjet da ga njegov sin, Petar (II.) Erdődy može otkupiti sa 17.000 forinti tijekom njezinog života. ${ }^{53}$

Suvremenicima je bilo očito da bi ogromni posjedi preko Ane Erdődy mogli doći u ruke obitelji Zrinski. Nikola Zrinski je bračnim ugovorom potpisanim pred zagrebačkim kaptolom 13. veljače 1557. stekao posjede Monyorókerék i Vörösvár (oboje u županiji Vas), te Csatár (u županiji Zala) ${ }^{54} \mathrm{U}$ zamjenu je obitelj Erdődy primila takozvano pravo nasljedstva nad Krbavom, s Medvedgradom u Zagrebačkoj županiji, Rakovec u Križevačkoj, 11.000 forinti i top u vrijednosti od 1.000 forinti. Razmjena je dogodila brzo i Nikola Zrinski, ne čekajući stvarne zaruke, naselio se u Monyorókeréku ${ }^{55}$ i postao najveći zemljoposjednik u županiji Vas, nakon Zale. ${ }^{56}$

\section{Stanje nakon dobivanja nove obiteljske rezidencije}

Stjecanje sigurnijih transdunavskih zemalja uzrokovalo je promjenu u obiteljskoj strategiji. Do tada su glavni teritoriji obitelji bili južno od rijeke Drave, pa nije bila slučajnost što je Nikola bio ban Hrvatske i Slavonije 15 godina. Međutim, na vlastiti je zahtjev Nikola bio premješten iz službe, a kralj Ferdinand I. imenovao je Petra (II.) Erdődyja kao njegovog nasljednika. O razlozima ove njegove odluke nadugo se raspravljalo u istraživanjima, a uglavnom se to objasnilo Nikolinim nezadovoljstvom i uvrijeđenosti prema Dvoru, budući da nikada od njega nije dobio dovoljno pomoći. ${ }^{57}$ Iako je to bila istina, mogao je to učiniti ranije, a ne odmah poslije uspješne vojne kampanje. Čini se nemogućim naći dokument koji bi rasvijetlio pozadinu ovoga, ali meni se čini da se povukao iz službe zbog ugovora potpisanog s obitelji Erdődy. Tako su Zrinski mogli dobiti veliki teritorij, koji im je omogućio da formiraju obiteljsko sjedište.

Prema izvorima, Monyorókerék je u drugoj polovici 16. stoljeća bilo obiteljsko središte, uz Čakovec, a kako je bio reprezentativan, ondje su organizirali vjenčanja, kao što je bilo ono Katarine Zrinski i Franje Thurzóa (1562.), Nikole Zrinskog (1564.), Doroteje Zrinski (1566.) ${ }^{58}$ Uršule Zrinski i Ivana Perényija, Barbare Zrinski i Eleka II. Thurzóa, Margarete Zrinski i Nikole Homonnaija Drugetha (1569.) te napokon Magdalene Zrinski i Emerika Thelekessyja (1584.). ${ }^{59}$ Iz ovoga se može pretpostaviti da su ženske članice obitelji živjele na sigurnijem posjedu u županiji Vas, i tijekom živo-

53 Povijesni muzej Budimpešta (dalje: BTM), Srednjovjekovni odjel (dalje: KO), Zbirka fotokopija diplomatičkih izvora (dalje: DF), no. 346. Želio bih zahvaliti Jánosu B. Szabi jer mi je omogućio vidjeti dokument.

54 Zrínyi Miklós a szigetvári hös, sv. 2, dok. 149, str. 346-349.

55 ÖStA, HHStA FAE Lad. 52. fasc. 4. no. 4. Zrinski je izdao pismo 26. listopada 1557. još u allodio nostro Weep (Zrínyi Miklós a szigetvári hös, sv. 1. dok. 312, str. 466).

56 Ferenc Maksay, Magyarország birtokviszonyai a 16. század közepén [Tipovi posjeda u Ugarskoj sredinom 16. stoljeća], sv. 2, Budapest 1990., str. 857-917, 1010.

57 Kálmán Benda, Zrínyi Miklós a szigetvári hős [Nikola Zrinski, heroj Sigeta], u: Szigetvári Emlékkönyv. Szigetvár ostromának 400. évfordulójára, ur. Lajos Rúzsás, Budapest 1966., str. 38-40.

58 Znamo da je Doroteja Zrinski živjela u Monyorókeréku prije svadbe te da je morala biti isprošena na tom mjestu. MNL OL MKA E 185, dokumenti iz arhiva Nádasdy III. fol. 142. 26. prosinca 1565. (MF 6924).

59 Pálffy, Egy horvát-magyar fóúri család, str. 50. 
ta Jurja Zrinskog, nakon Nikoline smrti, Monyorókerék je ostao značajna obiteljska rezidencija. Druge obiteljske građevine, u Ozlju ili Čakovcu nisu bile u suprotnosti sa spomenutom ulogom nove rezidencije. Tijekom osmanskog osvajanja u županiji Zala, rezidencija uz rijeku Muru nije mogla biti sigurno mjesto za širu obitelj. ${ }^{6}$ Činjenica da je Ivan Manlius postavio svoju tiskaru u Monyorókeréku pokazuje važnost mjesta, te treba naglasiti da je Manlius živio ondje u dva navrata, 1582. i 1592.-1593., prema nalogu Jurja Zrinskog. Dok je drugi put ondje živio, objavio je 14 mađarskih knjiga, i 1587. tiskao je prvi pamflet, koji je sadržao vojne vijesti (Neue Zeitung). ${ }^{61} \mathrm{Ju}-$ raj Zrinski, kao dobar vlasnik, uspio je dobiti potporu županije Vas za jačanje trgovišta Monyorókerék, ${ }^{62}$ a također je dobio i potvrdu za izuzeće Vépa od plaćanja poreza i tridesetnice (tricesima), ${ }^{63}$ i naposljetku je njegova udovica, Sofija Stubenberg, molila kralja da zaustavi sve parnice 1603. koje su se ticale Monyorókeréka. ${ }^{64}$

Da se vratimo na prvotno pitanje, vjerojatno je bila namjerna odluka da se prepusti banska služba Erdődyjevima, jer su se htjeli nastaniti za duže razdoblje u Transdanubiji. Juraj Zrinski htio se, povlačenjem s banske službe, usredotočiti na svoje posjede u županijama Vas i Zala, te dobiti titulu comes perpetuus. Povrh ovoga, dobio je titulu vrhovnog kapetana (supremus capitaneus) Transdanubije u Ugarskoj (1574.1575., te 1582.-1598.), a bio je također i kapetan Kaniže u tome razdoblju (1574.-1575., te 1582.-1590.). ${ }^{65}$ To bi moglo biti objašnjenje zašto nitko iz obitelji Zrinski nije obnašao važne službe u Slavoniji između 1557. i 1622. godine, i jedino ih je gubitak posjeda $\mathrm{u}$ Vasu natjerao da obiteljsko sjedište presele natrag u Međimurje te ponovno počnu sudjelovati u životu južnih provincija. Može se samo nagađati što se moglo dogoditi da je obitelj zadržala svoje pozicije u Transdanubiji tijekom 17. stoljeća, ne izgubivši ih zbog alkoholizma Nikole VI. Zrinskog. ${ }^{66}$

\section{Gubitak posjeda Erdődyja}

Život je ubrzo promijenio ugovor iz 1557. godine. Postoje dva glavna razloga za to: Petar Erdődy osnovao je novu obitelj, i vjerovao je da je ugovor o nasljeđivanju bio u korist Nikole Zrinskog. Može se smatrati božanskim utjecajem to što je 1557. teško bolestan udovac Petar Erdődy oženio Barbaru Alapić, i što su imali četvero djece: Tomu, Jelenu, Margaretu i Petra, koji su svi, osim Jelene, doživjeli odraslu dob.

60 Nije marginalno da su zadobili Vrbovec od obitelji Erdődy 1613., gdje su odmah stvorili obiteljsku rezidenciju, i gdje se rodio Petar Zrinski. Nataša Štefanec, IV. és V. Zrínyi György. [Juraj IV. i Jural V. Zrinski], u: A Zrínyiek a magyar és horvát históriában, str. 87-112, ovdje str. 97-99.

61 Isto, str. 101; Árpádné Zsigmondy, Johannes Manlius és nyomdakészlete (1575-1605) [Ivan Manlius i njegovi izdavački resursi (1575.-1605.)], u: OSzK Évkönyve 1982-1983., Budapest 1983., str. 297-410.

62 Péter Tóth, Vas vármegye közgyülési jegyzókönyveinek regesztái I. 1595-1600. [Regesta zaključaka županijskih skupština u Vas], Vas megyei levéltári füzetek 2. h.n., é.n., 24 (bez godine izdanja).

63 ÖStA, Hofkammer Archiv (dalje: HKA), Hoffinanz Ungarn (dalje: HFU), RN. 72. Konv. 1602. march., fol. 107-114.

64 ÖStA, HKA, HFU RN. 79. Konv. 1603. aug., fol. 297-300.

65 Štefanec, IV. és V. Zrínyi György, str. 93.

66 Isto, str. 88-89. 
Szabolcs Varga: “Kuća Zrinskih nije nikad bila istinski dom obitelji Erdődy”...

Zb. Odsjeka povij. znan. Zavoda povij. druš. znan. Hrvat. akad. znan. umjet., 34 (2016), str. 107-123

Novi članovi obitelji mogli su se s pravom osjećati zakinutima, budući da se trebalo bojati da će se s Anom, suprugom iz prvog braka, izgubiti svi posjedi Erdődyja. Nova je supruga 25. lipnja 1559. podigla tužbu protiv Zrinskih u samostanu u Kápolni, i tvrdila da, prema oporuci ostrogonskog nadbiskupa Tome Bakača, posjedi Erdődyja ne bi smjeli biti otuđeni od obitelji, te posebice jer je većina posjeda koje su primili od Zrinskih u Zagrebačkoj i Križevačkoj županiji opustošena te da jedva mogu imati ikakve prihode od njih. ${ }^{67}$ Moguće je da je Zrinski predosjetio preokret situacije budući da je tražio od Erdődyja da u rukama Zrinskih ostane samo Monyorókerék, koji je bio dan njegovoj ženi i kćerima. ${ }^{68}$ Ali do tog vremena sve je bilo odlučeno, budući da je 1563. godine bilo očito da neće biti nikakvog braka. Juraj Zrinski je pred požunskim kaptolom izjavio da se neće pridržavati ugovora. ${ }^{69}$ Nadalje, Ana se udala za Stjepana Dersffyja 1566., a Juraj je oženio Anu von Arc 1568. godine. ${ }^{70}$

Unatoč propalom braku, obitelj Zrinski mogla je desetljećima zadržati dobivene zemlje, uglavnom zbog toga što je obitelj Erdődy bila uključena u parnicu protiv obitelji Hásságyi, što bi moglo ugroziti vlasništvo obiteljske rezidencije u Körmendu. ${ }^{71}$ Tijekom ovog predmeta Petar I. Erdődy, koji je u tome trenu bio mrtav više od 15 godina, bio je kažnjen zbog svoje nasilne okupacije Körmenda i izgubio je pravo na svoje posjede, a Monyorókerék, Vörösvár i Csatár jedini su mogli preživjeti ovu presudu, budući da je kralj potvrdio bračni ugovor iz 1557., a istog dana potvrdio je presudu koja se ticala slučaja s Hásságyima. ${ }^{72}$ Zrinski nisu mogli iskoristiti situaciju i ojačati svoje pozicije.

Slučaj oko posjeda Erdődyja postao je kompliciraniji nakon 1567., kada su se Barbara Alapić i njezina djeca suočili s Anom Erdődy, te je njihov zatrovani odnos definirao odnose sedamdesetih godina 16. stoljeća. U siječnju 1570. Ana je tražila podjelu hrvatskih i slavonskih posjeda: Želina, Cesargrada, Okića, Lipovca, Jastrebarskog, Hrastovice i Novigrada, ali najvjerojatnije se to nije provelo u praksi. ${ }^{73}$ Postavši udovica rano, Ana se 1572. udala za Stjepana Illésházyja, koji je služio na očevom dvoru i koji joj je bio punopravni partner u obiteljskim poslovima. ${ }^{74} \mathrm{U}$ to vrijeme glavno pitanje bilo je ono vlasništva nad Körmendom, na čemu je ustrajao svaki član obitelji,

67 Zrínyi Miklós a szigetvári hős, sv. 2, dok. 114, str. 375-378; ÖStA, HHStA, FAE Lad. 52. Fasc. 4. no. 9. Citat iz: Bubryák, Családtörténet, str. 90.

68 Zrínyi Miklós a szigetvári hős, sv. 2, dok. 144, str. 486-487. Isto je navedeno u njegovoj oporuci napisanoj 22. ožujka 1561. (MNL OL P 1313 Acta Antiqua Lad. 8. No. 31).

69 Zrínyi Miklós a szigetvári hôs, sv. 2, dok. 135, str. 422-423.

70 Datum vjenčanja je 9. lipnja 1566. Usp.: Mikó - Pálffy, A pozsonyi Szent Márton templom, str. 131.

71 Petar Erdődy pozvao je Uršulu Kanižaj za vjenčanje njihove kćeri. Iako ime nedostaje, vjerojatno je bila riječ o Margareti Erdődy (MNL OL MKA E 185). Dokumenti iz arhiva Nádasdy III. fol. 148, 16. travnja 1567. (MF 6924).

72 Zrínyi Miklós a szigetvári hôs, sv. 2, dok. 121-122, str. 390-392.

73 ÖSta, HHStA, FAE Lad. 65. Fasc. 3. No. 31., Lad. 69. Fasc. 1. Citat u: Bubryák, Családtörténet, str. 90. Za 1575. vidi: MNL OL P 1314 Lad. 18. Fasc. 1. No. 13.

74 Katalin Péter, Illésházy Istvánról [O Stjepanu Illésházyju], Publicationes Universitatis Miskolciensis, sv. 13, fasc. 2, Miskolc 2008., str. 127-165, posebice str. 127-129, 141-142. Katalin Péter smatra da se vjenčanje dogodilo 1571., dok Géza Pálffy i Árpád Mikó misle da je bilo 1572. godine. Vidi: Mikó - Pálffy, A pozsonyi Szent Márton templom, str. 131. 
i slijedila su nasilja i optužbe jedna za drugom. Godine 1575., u odsustvu nadvojvode Karla Habsburškog, njegov brat Rudolf dao je Ani i Stjepanu pismo zaštite protiv službenika Tome Erdődyja, koji je par htio istjerati iz utvrde. ${ }^{75}$ Najprije nije ni smrt Ane Erdődy 26. lipnja 1577. promijenila situaciju, budući da se István Illésházy pomoću svojih utjecajnih prijatelja pobrinuo da zadrži svoj dio posjeda Körmend kao nasljedstvo. Štoviše, parlamentarni akt potvrdio je 1578. godine da Illésházy treba ponovno dobiti svoja prava na Körmend, nakon što ga je Barbara Alapić nezakonito izbacila. ${ }^{76}$ Međutim, najvjerojatnije se to nikad nije dogodilo, budući da su Toma Erdődy i njegov brat Petar (III.) mogli prodati 1595. svoje dijelove posjeda Ivanu Joóu, glavnom sucu Ugarske (personalis regiae), unatoč negodovanju Jurja Zrinskog, koji im je često zabranjivao da to učine..$^{77}$ Naposljetku, Körmend je 1604. godine pao u ruke obitelji Batthyány, i tijekom velike parnice obje su obitelji izgubile taj teritorij.

Tijekom 17. stoljeća obitelj Erdődy polako je nadmudrila Zrinske, bilo je samo pitanje vremena kada će doći do kraja slučaja. Smrt Jurja Zrinskog 1603. vjerojatno je igrala ključnu ulogu za promjenu situacije, budući da Nikola Zrinski nije mogao više parirati snazi Tome Erdődyja. Tijekom ovog slučaja, jedan od glavnih problema bila je i činjenica da su Erdődyjevi dali u zalog posjede koje su primili od Zrinskih; tako su primjerice dali u zalog Medvedgrad Ambrozu Gregorijancu 1559. i posjed je popisan među obiteljskom imovinom na kraju stoljeća. ${ }^{78} \mathrm{Za}$ Gregorijance treba napomenuti da su imali prisan odnos s obje obitelji, i Zrinski i Erdödy, a već spomenuti Ambroz služio je pod Nikolom Zrinskim kao kaštelan Medvedgrada, a pod Petrom Erdődyjem kao viceban. Gregorijanci su izumrli u prvom desetljeću 17. stoljeća smrću Nikole, a jedna od njegovih kćeri, Anamarija, udala se za Petra IV. Erdődyja, što je vjerojatno pomoglo tijekom intenzivnijih pregovora 1612. godine.

Nikola Zrinski je kočio dogovor, budući da nije htio Erdödyjima vratiti natrag Vörösvár, Vép i Csatár, već ih je želio zadržati prema nasljednom dogovoru. Štoviše, u zamjenu za Monyorókerék, tvrdio je da je dao 12.000 forinti prilikom sklapanja ugovora, uz dodatak novca što ga je potrošio za otkup zemlje koju su Erdődyji dali u zalog. Nikola se opravdavao tvrdeći da je njegov djed sagradio mlin i ribnjak na posjedu i napravio mnoštvo radova kako bi oživio teritorij. ${ }^{79}$ Toma Erdődy je odgovorio da bi on sagradio mnogo toga da su mu posjedi pripadali 60 godina, ali treba napomenuti da se zaista, kada je posjed bio u vlasništvu obitelji Zrinski, ozbiljno gradilo na posjedu, i čak je 1592. ondje navedeno nekoliko stotina novih hrvatskih naseljenika.$^{80}$ Naposljetku, 1613. “ban Toma Erdődy dobio je Monyorókerék tijekom parnice od Zrinskih, i zauzeo ga je 4 . svibnja" ${ }^{81}$ Toma Erdődy uzeo je natrag

75 MNL OL P 1314 Lad. 18. Fasc. 1. No. 8.

76 Corpus Juris Hungarici, 1578, doc. 32.

77 Tóth, Vas vármegye, str. 5-7.

78 Josip Adamček - Ivan Kampuš, Popisi i obračuni poreza u Hrvatskoj u XV. i XVI. stoljeću, Zagreb 1976., str. 181, 184.

79 ÖStA, HHStA, FAE Lad. 52. Fasc. 4. no. 28.

80 Štefanec, Heretik Njegova, str. 43-44, 170-171

81 Pethő, Rövid magyar krónika, str. 180. 
Szabolcs Varga: “Kuća Zrinskih nije nikad bila istinski dom obitelji Erdődy”...

Zb. Odsjeka povij. znan. Zavoda povij. druš. znan. Hrvat. akad. znan. umjet., 34 (2016), str. 107-123

Vép, Monyorókerék i Vörösvár, i u zamjenu za to otkupio je za 1.000 talira i 1.300 forinti Medvedgrad za obitelj Zrinski od Anamarije Ainkern, udovice Nikole Gregorijanca. ${ }^{82}$ Dakle, parnica je završila ovako: Toma Erdődy je dobio sve natrag, ali je trebao otkupiti Medvedgrad i vratiti već rečenih 12.000 forinti. Finalni dogovor još nije bio postignut godinama, a posjedi u Vasu vratili su se Erdődyjima tek 1617. godine. ${ }^{83}$ Međutim, u to vrijeme sve ovo više nije bilo važno, budući da je tada novo obiteljsko sjedište Erdődyja bio Varaždin, a varaždinska županija njihov uži dom, dok su Zrinski počeli graditi Vrbovec, odmah do Čakovca.

\section{Epilog}

Međusobni odnosi dviju obitelji uvijek su zanimljiva tema, pogotovo ako se radi o Zrinskima. Istraživanje je prikazalo eru brakova i bilo je poučno vidjeti kako određeni događaju mogu promijeniti sudbinu obitelji, kako prigovori Petra Erdődyja mogu prouzrokovati da Zrinski promijene svoju strategiju. Duga parnica jasno je ocrtala karakteristike proučavanog razdoblja, u kojem se sve vrtjelo oko održavanja i osnaživanja obiteljske moći, a kvaliteta glave obitelji često je bila presudan faktor. Nije bila slučajnost što je obitelj Erdődy trpjela poraze sa svih strana sedamdesetih godina 16. stoljeća kada je Toma Erdődy bio maloljetan, a dobili su iste parnice tijekom prvog desetljeća 17. stoljeća. Odnos dviju obitelji ostao je hladan tijekom 17. stoljeća, i nisu ga ni pokušali učvrstiti ni rođačkim vezama. Ne bih htio započeti s novim razmišljanjima, ali potrebno je spomenuti da je obitelj Erdődy slavila samo Pirove pobjede. Iako su dobili natrag svoje posjede, njezina slava i čast nisu porasle, štoviše, dugotrajna parnica sa Zrinskima okaljala je njihov ugled. Zahvaljujući tomu, slika kojom Nikola Istvánffy oslikava Tomu Erdődyja manje je laskava, ${ }^{84}$ a isto tako se može vidjeti određeni damnatio memoriae u Kronici Grgura Pethőa, kada je u tiskanoj verziji djela posveta Tomi Erdődyju bila izostavljena. ${ }^{85}$ Iako izgubljena parnica nije uzrokovala nikakvu štetu slavi obitelji Zrinski, ime obitelji Erdődy bilo je okaljano, unatoč nepravdi koju su pretrpjeli.

Prevele Judit Gál i Sanja Miljan

82 Nada Klaić, Medvedgrad i njegovi gospodari, Zagreb 1980., str. 274-275.

83 Péter Dominkovits, Rokonok és pénzügyek. A szombathelyi polgárok kereskedelmi kapcsolataikról végrendeleteik alapján (1606-1665) [Rođaci i financije. O trgovačkim odnosima građana Szombathelya prema njihovim oporukama), Urbs - Várostörténeti Évkönyv, sv. 3, Budapest 2008., str. 285.

84 Istvánffy Miklós Magyarok dolgairól irt históriája Tállyai Pál XVII. századi fordításban [Kronika Nikole Istvánffyja o Mađarima prema prijevodu iz 17. stoljeća Pála Tállyaija], sv. I/3, prir. Péter Benits, Budapest 2009., passim.

85 Nagy, Pethő Gergely, str. 288. 
Szabolcs Varga: "Kuća Zrinskih nije nikad bila istinski dom obitelji Erdődy"...

$$
\text { Szabolcs Varga }
$$

\title{
"The House of the Zrinski/Zrínyi Was Never Truly a Home for the Erdődy Family". A Chapter from the Relations between the Families of the Zrinski and the Erdődy in the Early Modern Period
}

\begin{abstract}
Summary
This article compares the Erdődy family, of Hungarian origin, and the Zrinski/Zrínyi family, of Croatian origin. The reason for the comparison of the families is obvious: they both held the office of the ban of Croatia-Slavonia during the majority of the period under research, so they were the most honourable families of the region at that time. Interestingly, while the Zrinski/Zrínyi family held the office for 40 years, with four members of the family being bans, the five members of the Erdődy family were bans for more than 70 years. Through the comparison of their actual accomplishments, it can be seen that the Zrinski/Zrínyi family was removed from power and lost their estates, and by the eighteenth century they had become extinct. Their achievement is highly questionable, because despite their military successes they could not prevent the continuous ruin of Croatia and Slavonia. We know much less about the activity of the Erdödy family, but the careers of Peter II Erdődy, Thomas Erdődy and Nicholas Erdődy were outstanding, and the latter two had significant success in the political and military fields as well. Despite all this, regarding the level of appreciation, they dropped far behind the Zrinski/Zrínyi family, and no cult formed around them like the one that developed in the cases of Nicholas IV Zrinski/Zrínyi of Szigetvár, and Peter Zrinski/Zrínyi, executed in Wiener Neustadt. Finally, although there were three attempts at marriage between the families, these never succeeded, and so a strange situation came about: the two most powerful dynasties of the region were not directly related.
\end{abstract}

Key words: social history, political history, Slavonia, Croatia, the Zrinski/Zrínyi family, the Erdődy family 